\title{
Livelihoods and Capital Formation of Tribal Hill Farmers in Intermediate Zone of J\&K, India
}

\author{
Naseem A. Qammer, F.A. Shaheen*, S.A. Wani, Nageena Nazir, \\ F.A. Lone and S.A. Simnani
}

Sher-e-Kashmir University of Agricultural Sciences and Technology of Kashmir, Shalimar, Srinagar, India

*Corresponding author: fashaheen@rediffmail.com

Received: $21-08-2020$

Revised: 25-11-2020

Accepted: 03-12-2020

\begin{abstract}
Hill agriculture plays an important role in sustaining livelihoods of marginal and nomad communities. With the onslaught of liberalization and climate change, the mountain communities are at cross-roads. In order to sustain the livelihoods and capital assets of mountain farmers, a study was undertaken in the inter-mediate zone of Jammu and Kashmir. The study was conducted during the period 2018-2020, covering two inter-mediate hill districts viz. Rajouri and Poonch. Data sources include both primary as well as secondary information. The primary data was collected from a sample of 251 farm households representing 25 villages, 4 blocks and 2 districts. The selection of villages and farm households from the study area was carried from low, medium and high altitude areas ranging from $800 \mathrm{~m}$ amsl to $1500 \mathrm{~m}$ amsl. Primary data was collected by administering pre-tested questionnaire through personal interview method. The secondary data/information was collected from different sources/ departments, websites etc. The primary data was tabulated and analysed using averages, ratios and percentages and through giving ranks. The factors which influenced livelihood strategies of farm household were broadly classified into human capital, natural capital, physical capital, financial capital and social capital. Households residing in upper and middle zones were more dependent on natural capital assets for their livelihoods which mostly comprise on forest resources while as people residing in lower zones were more dependent on market driven capital assets such as jobs, commerce etc. Hills and hill agriculture is important as they support the plains through provision of ecosystem services, besides taking care of themselves. To sustain the smallholder farming of tribal hill communities, there is a need of multi-pronged strategy at various levels. As majority of the intermediate zone is a rainfed area, so more focus should be brought towards rainfed technologies with more emphasis on integrated watershed development programs in a holistic approach.
\end{abstract}

Keywords: Livelihood, capital assets, intermediate zone, hill farmers, J\&K

Mountains play a crucial role in sustaining about 10 per cent of the world population directly. The major mountain ranges in India are the Himalayas and the Western Ghats. The Himalayan hill and mountain areas lying within India fall into two distinct geographical regions viz., North West Himalayan region and North East Himalayan region with wide variation in climate, land use and culture. The union territory Jammu and Kashmir has mostly a mountainous area and occupies a central position in the continent of Asia. Out of 3.5 million ha of mountainous area of India, nearly two-third i.e. 2.3 million hectares are found exclusively in Jammu

How to cite this article: Qammer, A.N., Shaheen, F.A., Wani, S.A.,
Nazir, N., Lone, F.A. and Simnani, S.A. (2020). Livelihoods and Capital
Formation of Tribal Hill Farmers in Intermediate Zone of J\&K, India.
Agro Economist - An International Journal, 7(2): 101-111. Source of Support: None; Conflict of Interest: None 
and Kashmir. The UT lies in the extreme north of the Himalaya and constitutes about 67.5 per cent of the North West Himalayan region which extends between $32^{\circ}$ and of $37^{\circ}$ North parallels of latitude and $73^{\circ}$ and $80^{\circ}-30^{\circ}$ East of meridians of longitudes and $81^{\circ}$ East of Greenwich. This geographical position, coupled with the varied physiography, provides the UT a wide climatic variation. The UT has been divided into four broad macro-climatic zones. These are sub-tropical Jammu region (up to $800 \mathrm{~m}$ masl), intermediate/semi temperate mid hills (800-1500 m masl), temperate Kashmir valley (1500-2500 m masl) and cold arid zone of Ladakh (>2500 m masl) (Anonymous, 2011). Rajouri and Poonch are the two important mountainous districts which fall in intermediate agro-climatic zone. Inter-mediate zone is transition between sub-tropical and temperate and comprises of the mid and high altitude areas of the Panjal trap. The zone is characterized by monsoon, concentration of precipitation, relatively wetter, cold winters and higher mean annual rainfall than subtropical zone. It encompasses all the areas above hills including district Doda, Poonch, parts of Rajouri and Udhampur. The zone varies in elevation from 800 to $1500 \mathrm{~m}$ masl. Rajouri and Poonch districts fall in Pir Panchal belt of Jammu division. The two district have a total population of about 8.48 lakh and an area of 3.61 lakh ha with net sown area and gross sown area of 3.26 lakh ha and 6.07 lakh ha respectively. The district Rajouri have a total forest area of about 94.85 thousand ha likewise, forest cover area in district Poonch is 34.05 thousand ha (Anonymous, 2017).

The Hindu Kush Himalayan region provides vast natural resources to support livelihoods needs - food, energy, shelter, medicine, cash and savings, and feed for livestock and raw materials for industry (Rasul and Karki, 2007). Beside mountain agriculture largely depends on the interactions of crops, horticulture, livestock, rangelands and forest, there is also diversity in livelihoods of mountain communities at every level, for example, members of a household may work in different places engaging in various activities, either temporarily or permanently. Due to the increased importance of off-farm income in household livelihood, livelihood's diversification has generally occurred. Livelihood strategies consist of how people engage in and combine different income generating activities, how they use different resources and how much these resources influence household livelihood strategies.

Among the most marginalized sections in India, people are living in geographically fragile areas like the Himalayas, where conventional agricultural and industrial developments face severe constraints. Mountain communities are plagued with the problem of vulnerability which affects their livelihood. Sustainable livelihood includes the idea of coping with and recovering from stress and shocks, and maintaining or enhancing existing capabilities and assets both now and in the future, while not undermining the natural resource base (Carney, 1998). The hilly areas always remained socially and economically backward. Mountain livelihoods are associated with fragile agro-ecosystem, inaccessibility, marginality, very less off-farm opportunities and niche conditions with inherent constraints of under pressure from natural and human-induced stresses which reduces the livelihood sustainability and also increases the level of vulnerability to various shocks, risks trends etc. The rich environmental heritage of the Himalayan region is considering the poor scope for industrialisation in mountains and perspective of rural livelihood. Added to this, there are also some socioeconomic constraints that, primarily, include small land holdings, poor productivity, poor production management, labour shortages, poor post-harvest management, poor market networks (lack of market development) and lack of entrepreneurship etc. All these factors have led to under-utilization of available resource base leading to limited generation of economic surpluses.

The actual pressure on sloping hills and mountains on the agricultural land is much greater to support food security and livelihood of the mountain people (Pratap, 2001). The problem of shrinking agricultural land is getting compounded with new human settlements, urbanization, and industrialization and government infrastructure developments, which would threaten food security and livelihoods in the mountains (Gardner, 1996).

\section{MATERIALS AND METHODS}

The present study was set out to assess livelihoods in the intermediate zone of $J \& \mathrm{~K}$ through the combined use of secondary information and village level 


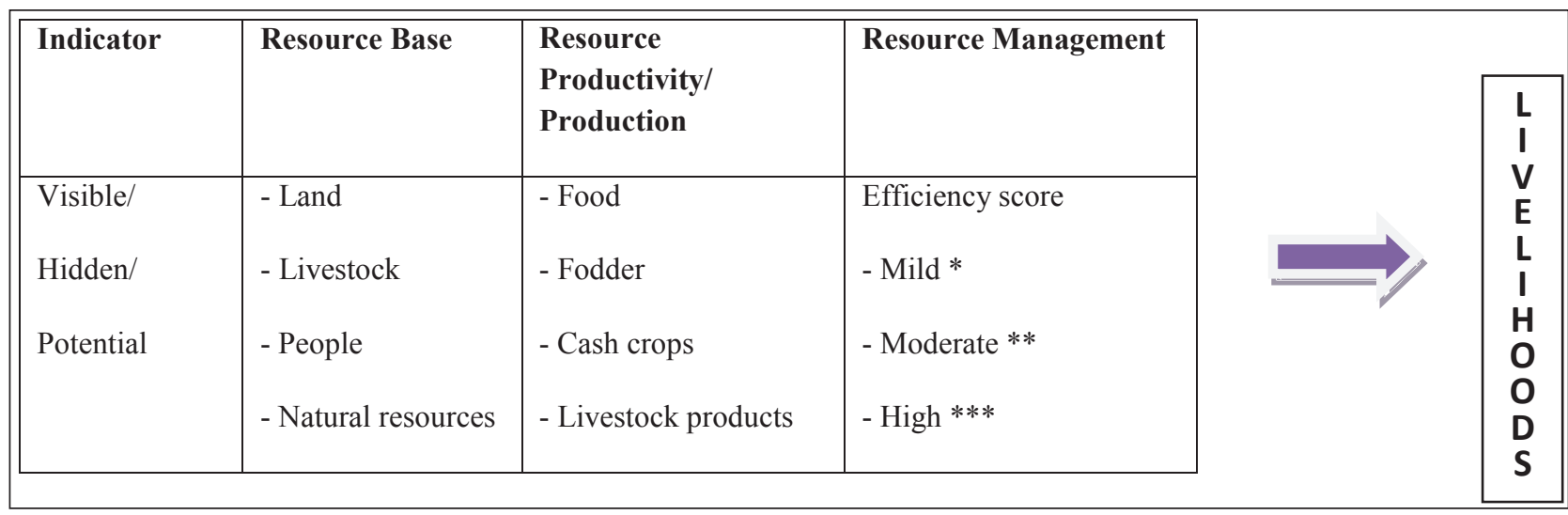

Fig. 1: Indicators of Livelihood

surveys. In order to better dissect and understand livelihoods and the contribution of crops, livestock, other sectors and interaction of the sample village communities, the scoping study took its analytical framework from the following model.

The framework provides a systematic way of (i) evaluating the natural and household assets (resource base), (ii) then analyse the productivity of present resource base, (iii) how these influenced decisions on resource management and (iv) describing and understanding current livelihood strategies and then exploring the options for reducing poverty and addressing issues of sustainability.

The main primary data source for the livelihood survey of tribal households were collected using well-structured questionnaire and also included interaction with sarpanchs, village elders and field functionaries associated with different aspects of livelihood options. The secondary data on various aspects of the study area were collected from relevant sources and departments such as District Animal and Sheep Husbandry Offices, Agriculture/Forest/ Irrigation departments and District Statistical and Evaluation Agency of Rajouri and Poonch districts, several reference works like Economic Review of districts and Village Amenities Directory etc.

The village survey used semi-structured interviews using a survey instrument. A village leader (sarpanch) provided the quantitative descriptions of the village (people, resources, and infrastructure). Group and individual discussions with respondents described the crop and livestock sub systems practiced in the village and other significant aspects of village livelihoods. Discussions with the respondents also identified constraints and opportunities for improving their livelihoods and that of the village. The quantitative primary data from the village surveys were summarised using descriptive statistics

Among twenty villages, six villages fall in lower zone having altitude range from 800- 1000 mamsl, seven villages fall in middle zone (1000-1300 m amsl) and twelve villages fall in upper zone having altitude range from 1300-1500 mamsl (Table 1).

\section{RESULTS AND DISCUSSION}

\section{Livelihood and Capital Formation}

The livelihood comprises the capabilities, assets (including both material and social resources) and ...activities required for means of living. Sustainable livelihood means capability of coping with and quick recovery from stress and shocks to maintain capabilities and assets, without undermining the natural resource base.

The livelihood framework is a tool to improve our understanding of livelihoods, particularly the livelihoods of the poor. The sustainable livelihoods framework presents the main factors that affect people's livelihoods, and typical relationships between these. It can be used in both planning new development activities and assessing the contribution to livelihood sustainability made by existing activities. The livelihood framework identifies five core asset categories also known as asset pentagon upon which livelihoods are built, these are (i) human capital, (ii) social capital, (iii) natural capital, (iv) physical capital and (v) financial capital. The livelihood construction and capital formation among 
Table 1: Details of villages selected in the study area

\begin{tabular}{|c|c|c|c|c|c|}
\hline Agro-Climatic Zone & District & Block & Villages & Altitude (masl) & Altitude Zone \\
\hline \multirow{25}{*}{ 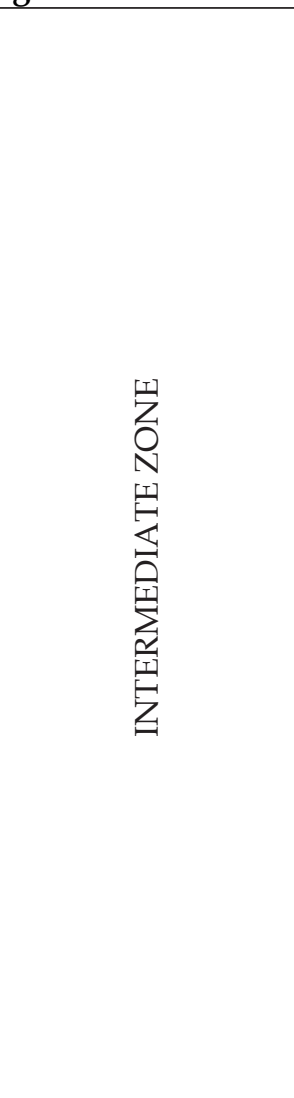 } & \multirow{13}{*}{ Rajouri } & \multirow{8}{*}{ DoongiAgrati } & Kaller & 859 & Lower \\
\hline & & & LoorKote & 800 & Lower \\
\hline & & & Kheri & 901 & Lower \\
\hline & & & Shahpur Manialla & 998 & Lower \\
\hline & & & Ghai & 1026 & Middle \\
\hline & & & DharaSamla & 1171 & Middle \\
\hline & & & Doongi Brahma & 972 & Lower \\
\hline & & & TotaMorah & 1297 & Middle \\
\hline & & \multirow{5}{*}{ Thanna Mandi } & Behrote & 1496 & Upper \\
\hline & & & Dharamsiot & 1500 & Upper \\
\hline & & & Charung & 1350 & Upper \\
\hline & & & Rajdhani & 1300 & Upper \\
\hline & & & Kaller & 1400 & Upper \\
\hline & \multirow{12}{*}{ Poonch } & \multirow{7}{*}{ Balakote } & Dabsi & 1291 & Middle \\
\hline & & & Panjani & 1476 & Upper \\
\hline & & & Dhrauti & 1461 & Upper \\
\hline & & & Broti & 1489 & Upper \\
\hline & & & Nar & 1495 & Upper \\
\hline & & & Lanjote & 1420 & Upper \\
\hline & & & Jaggal & 992 & Lower \\
\hline & & \multirow{5}{*}{ Mendhar } & Chattral & 1098 & Middle \\
\hline & & & Pathantir & 1141 & Middle \\
\hline & & & Sakhimaidan & 1350 & Upper \\
\hline & & & Gohlad & 1369 & Upper \\
\hline & & & Ari & 1220 & Middle \\
\hline
\end{tabular}

tribal mountain households of inter-mediate zone is discussed under this framework.

\section{Human Capital}

At the household level, human capital is a function of knowledge, health, the quality and quantity of available labour, and livelihood relevant skills. The results obtained from the household survey are comparable with several human capital indicators; the percentage of respondents who had received at least primary education was 43 per cent. As many of the survey respondents finished their education a long time ago, the current level of 87 per cent enrolment in primary education is indicative of progress towards the second Millennium Development Goal (MDG), achievement of universal primary education.

Health facility is one of the major factors for livelihood assets, and which ultimately affects the livelihood of the people. Distance from settlement determines the context of vulnerability, and level of risk that people had been suffering (Table 2). All the sampled villages in lower zone fall in block Doongi Agrati of district Rajouri and only one sampled village from district Poonch i.e., Jaggal fall in lower zone. There is no any sub district hospital in block Doongi Agrati but there is sub district hospital in block Mendhar, Balakote of District Poonch and in Block Thanna Mandi of district Rajouri.

Regarding Primary Health Centre (PHC), respondents who are living in upper zone have low accessibility and people of lower and middle zone having high accessibility. There is no sub centre/village dispensary in lower zone. However, there is high accessibility of people living in upper and middle zones for sub centre/village dispensaries. About 74 per cent of people have high accessibility of private medical shops and small clinics in lower zones and 26 per cent of people have moderate accessibility. The people living in middle and lower zones have moderate accessibility towards medical shop. As 
far as private doctors are concerned there is low private practice in lower zone where as moderate accessibility of such service in middle and upper zone. The accessibility of district hospital is high in lower and middle zones and low in upper zone.

Table 2: Access to health facilities

\begin{tabular}{llll}
\hline Health Care Sources & $\begin{array}{l}\text { Lower } \\
\text { zone }\end{array}$ & $\begin{array}{l}\text { Middle } \\
\text { zone }\end{array}$ & $\begin{array}{l}\text { Upper } \\
\text { zone }\end{array}$ \\
\hline $\begin{array}{l}\text { Sub District Hospital } \\
\text { Primary Health Centre }\end{array}$ & $* * *$ & $* * *$ & $* *$ \\
$\begin{array}{l}\text { Sub centres/Village } \\
\text { dispensary }\end{array}$ & - & $* * *$ & $*$ \\
Medical Shop & $* *$ & $* *$ & $* *$ \\
Private Doctor & $*$ & $* *$ & $*$ \\
District Hospital & $* * *$ & $* * *$ & $*$ \\
\hline
\end{tabular}

Note: * Low accessibility, ** Moderate accessibility, *** High accessibility.

Extension of programs and technologies in agriculture and allied sectors has a great role in capital formation. Among the Agriculture extension office, Horticulture development office, and Animal and sheep husbandry department, the latter one has high accessibility in lower and middle zones (Table 3) whereas all of the other agencies have low accessibility in upper zone. People have low accessibility to officials and extension workers of SKUAST-J/KVK, and agriculture related programs in almost all zones.

Table 3: Access to Agricultural/ Animal Husbandry information

\begin{tabular}{llll}
\hline $\begin{array}{l}\text { Information Source/ } \\
\text { Extension agency }\end{array}$ & $\begin{array}{l}\text { Lower } \\
\text { zone }\end{array}$ & $\begin{array}{l}\text { Middle } \\
\text { zone }\end{array}$ & $\begin{array}{l}\text { Upper } \\
\text { zone }\end{array}$ \\
\hline $\begin{array}{l}\text { Agricultural Extension } \\
\text { Officer }\end{array}$ & $* *$ & $*$ & $*$ \\
$\begin{array}{l}\text { Horticulture Development } \\
\text { Officer }\end{array}$ & $* *$ & $* *$ & $*$ \\
$\begin{array}{l}\text { Animal and Sheep } \\
\text { Husbandry Deptt. }\end{array}$ & $* *$ & $* * *$ & $*$ \\
$\begin{array}{l}\text { SKUAST-J/KVK } \\
\text { Other farmers }\end{array}$ & $*$ & $*$ & $*$ \\
Seed/Input suppliers & $* * *$ & $* * *$ & $* * *$ \\
Media & - & - & - \\
\hline
\end{tabular}

Note: * Low accessibility, ** Moderate accessibility, *** High accessibility.
However, high accessibility of farmers was observed with other farmers and input supplier as later store the seeds and fertilizers in their respective shops and are the major suppliers of essential farm inputs to the famers. There is almost negligible role of Rajouri and Poonch district local media related to dissemination of agriculture/animal husbandry information.

\section{Natural capital}

Natural capital is the term used for the natural resource stocks from which resource flows and services (e.g. nutrient cycling, erosion protection, watershed services, biodiversity etc.) useful for livelihoods are derived. There is a wide variation in the resources that make up natural capital, from intangible public goods such as the atmosphere and biodiversity to divisible assets used directly for production (trees, land, water, pastures, NTFPs etc).

Table 4: Natural capital and access to resources

\begin{tabular}{llll}
\hline Natural Capital & $\begin{array}{l}\text { Lower } \\
\text { zone }\end{array}$ & $\begin{array}{l}\text { Middle/ } \\
\text { central zone }\end{array}$ & $\begin{array}{l}\text { Upper } \\
\text { zone }\end{array}$ \\
\hline 1. Land(ha) & 0.46 & 0.51 & 0.57 \\
\hline 2. Livestock & & & \\
\hline i) Buffalo & 1.52 & 1.95 & 2.24 \\
ii) Cow & 0.18 & 0.06 & 0.05 \\
iii) Calf & 0.34 & 0.6 & 0.47 \\
iv) Bullock & 0.10 & 0.08 & 0.19 \\
v) Sheep and goats & 1.85 & 1.92 & 3.45 \\
vi) Horses & 0.04 & 0.14 & 0.11 \\
\hline 3. Water resources & $* *$ & $*$ & $*$ \\
(availability) & & & \\
\hline 4. Natural Resource & & & \\
Collection & & & $* * *$ \\
\hline i) Fuel Wood & $*$ & $* *$ & $* *$ \\
ii) Grass & $*$ & $* *$ & $* * *$ \\
iii) NTFPs & $*$ & $* *$ & \\
\hline
\end{tabular}

Note: * Low accessibility, ** Moderate accessibility, *** High accessibility.

Natural capital is an important component of livelihood asset basket among the residents of intermediate zone, particularly the dependence on this asset set was found of high degree among the pastoralist group living at higher altitudes. The natural capital assets of households expressed in absolute metric units as well as in relative terms are depicted in Table 4. On an average, the land holding 
in lower zone is 0.46 ha followed by 0.51 ha in middle and highest in upper zone of study area, i.e. 0.57 ha. Livestock forms an important component in this asset basket and as important livelihood option. Hence, they are an integral part of household economy. Household living in hilly areas have their own livestock in the form of buffalo, cow, calf, bullock, sheep and goats, horses etc. Average number of cow per household was low across all the three zones than buffalo. Average number of bullocks was observed relatively high in upper zone as they are reared for ploughing purpose on difficult terrains while tractorization is impossible or out of reach. Likewise, rearing and domestication of small ruminants (sheep and goat) is more among high altitude households as they majorly belong to pastoralist communities.

The use of natural resources from common lands as well as forest fringes in form of collection of fuel wood, grass for livestock and other NTFPs was of higher order in upper zone villages than that of lower zone areas. However, lower zone villages were found to have better water supply due to piped water supply schemes in those areas as compared to people living in upper zones who were found restricted with scanty water sources of natural springs which are also now drying up due to climate change as reported by the people living in such areas.

\section{Physical capital}

Infrastructure components such as road and affordable transport network, secure shelter and buildings, adequate water supply and sanitation, clean and affordable energy and access to information (telecommunication network) etc., are essential for sustainable livelihoods. Infrastructure is commonly a public good that is used without direct payment. Exceptions include shelter, which is often privately owned, and some other infrastructure that is accessed for a fee related to usage (e.g. toll roads and energy supplies). Producer goods may be owned on an individual or group basis or accessed through rental or 'fee for service' markets, the latter being common with more sophisticated equipment.

Physical capital is a function of the existing infrastructure, which may be freely or nominally accessible to households in the location, and the implements available for assistance with livelihood construction. It is therefore necessary to consider both the existing infrastructure and the generation and variation of household physical capital, and how this varies by a range of factors. Infrastructure that is generally accessible to all the population in the study area includes the road and transport network. Resources that may necessitate payment for usage include water, telecommunication services, machinery to assist agricultural production, particular forms of energy consumption and educational establishments.

The present study has presumed that insufficient or inappropriate production of physical goods and services can constrain people's productive capacity. In this study physical assets were housing materials, housing goods, and other gadgets of the houses that are essential for the community to live their daily lives. Physical assets include basic infrastructures and producer goods which are essential to support livelihood such as access to road, electricity, water supply and access to communication facility among the tribal hill farmers. Like other assets, there are several common assets which affect the livelihoods of households. These assets are road, water facility, electricity, communication, and other services and their availability as well as accessibility for people living in these areas. Infrastructure plays a very important role in analysing the economic condition of households.

The physical capital as well as its accessibility and usage were determined through qualitative information on the variables across the three zones which is summarised under Table 5. The information reveals varied degrees of physical asset either under public or private domain along with their usage and accessibility. The physical assets apart from own private capital assets also comprises of public infrastructure goods and services which creates efficiency and effectiveness in production process as well as livelihoods and overall living standard. These are discussed under following sub-headings.

\section{Road and transport facility in study area}

Road and transport facility is an important determinant in development and welfare of a given region. Lower zones were observed with moderate road network while as middle and upper zones had poor road infrastructure. Availability of transport was of average order in lower and middle zones 
Table 5: Physical capital assets across the various zone

\begin{tabular}{llll}
\hline Particulars & Lower zone & Middle/central zone & Upper zone \\
\hline (A) Road and transport & & & \\
\hline Road network connection & Moderately & Poorly & Poorly \\
Quality of roads & Average & Very poor & Very poor \\
Availability/ Affordability of transport service & Average & Low & Low \\
\hline (B) Building Infrastructure & & $70 \%$ & $73 \%$ \\
\hline i) Mud and stone house & $50 \%$ & $20 \%$ & $17 \%$ \\
ii) Stone with concrete & $32 \%$ & $10 \%$ & $10 \%$ \\
iii) Brick with concrete & $18 \%$ & & Poor \\
\hline (C) Water Supply and Sanitation & & Poor & Poor \\
\hline i) Piped drinking water & Good & Poor & Poor \\
ii) Availability of water & Average & Poor & Poor \\
iii) Quality of water & Average & Poor & Poor \\
iv) Timeliness of water & Average & Poor & $8 \%$ \\
v) Sanitation & Average & $20 \%$ & $*$ \\
vi) Toilet facility available to & $72 \%$ & & $*$ \\
(D) Energy Source and Access & & $* *$ & $*$ \\
i) Cooking gas & $* * *$ & $* *$ & - \\
ii) Wood & $* *$ & - & $*$ \\
iii) Manure cakes & - & $* *$ & $*$ \\
iv) Electricity & $* *$ & $* * *$ & $*$ \\
\hline (E) Telecommunication Network & $* * *$ & $* * *$ & \\
\hline i) Cell phone & $* *$ & & $*$ \\
ii) TV & $*$ & $* *$ \\
iii) Radio service & & & $*$ \\
\hline
\end{tabular}

Note: * Low accessibility, ${ }^{* *}$ Moderate accessibility, ${ }^{* * *}$ High accessibility.

where as poor transport facility was found in upper zone. The internal road network leading to villages are not macadamized and are usually gravelled with major portions damaged. Transport is very scanty which ends up in long waits and wastage of time. In middle and upper zones, number of villages is still not connected properly with roads. Therefore, the transportation connectivity is lacking in such areas. In nut-shell, the high altitude areas lag behind in mobility and connectivity with no public transportation system. Due to this, they are not able to take the advantage of road networks which ultimately limits their livelihood strategies and make a household more vulnerable especially during sickness, expecting mothers, etc., as they cannot reach hospital on time and can pose a severe threat to the life.

\section{Building Infrastructure}

Availability of wood logs and stone in the upper reaches of hilly areas makes these materials cheaper than other house-making materials. So, majority of houses are log-wood houses with stone as basal material. The poor housing asset of the respondents had different implications to the livelihood strategies and assets. It largely affected their livelihood security and social prestige in the society. About 73 per cent of respondents living in upper area have houses made up of mud and stone with roof stand on log-wood and soil and only 10 per cent of respondents have houses made up of cement and stone where leftover 10 per cent of respondents have pacca houses. In lower zone 50 per cent of respondents have houses made up of mud and stone, 18 per cent have pacca houses and 32 per cent have houses made up of stone and cement. In middle zone only 10 per cent of respondents have pacca houses, 70 per cent have houses made up of stone and mud and 20 per cent have houses made up of cement and stone. 


\section{Water supply and sanitation}

The sanitation and access to proper toilets is the basic condition to live and is one of the major components of physical asset. The availability of natural water resource which includes stream, spring, in the community has started to recede during last couple of years and such resources are far from their houses which takes a lot of time of women folk to collect it from its natural source. There is poor availability of piped drinking water, quality of water, and sanitation in upper and middle zones (Table 5). However, there is average facility of piped drinking water for short periods in lower zone of the study area. It can be observed that higher proportion of respondents of higher altitude areas were not satisfied with the current situation of drinking water facility. The results presented in Table 5 shows that most of the households (72\%) had built their toilets in lower zone while as its proportion in middle and upper zones was abysmally very poor and majority are still acquainted with open sanitation in such areas .

\section{Energy source and access}

The electricity is a basic infrastructure as a source of energy which has both direct and indirect contributions to livelihood and quality of life. Time as well as quality of electricity supply is very poor in upper zone, however, average in lower and middle zones as reported by the respondents. When they were asked the "purpose of using electricity", almost the households answered that they used for lighting because the quality of light was very poor and cannot be used for cooking purpose. Wood is used for cooking purpose through traditional means known as Chulas. Almost every household has cooking gas and cylinder after the launch of Pradhan Mantri Ujjwala Yojna scheme 2016 under which government provided free LPG connections to women of Below poverty line families and also priorities to household belonging to SC and ST category. The subsidized amount is credited in the saving bank accounts of the women who applied for this on refilling of the cylinder, but beside this women folk are still using wood as fuel.

\section{Telecommunication network}

The communication asset of the upper region of hilly area was found poor in comparison to other zones. The study revealed that 99 percent of the total household have access to mobile phones. However, all of them do not have smart phones. Radio service is abundantly used by people living in upper and middle zone. However its usability is low in lower zone of study area. It could also be possible that due to the hilly and mountainous geographic location which cause difficulty in providing good network facilities as main reason for poor connectivity. Television affordability was seen moderate in lower zone however, it is very low or minimal in middle and upper zones.

\section{Financial capital}

Financial assets denote income flows from various sources that people use to achieve their livelihoods. These assets comprise of the availability of cash or equivalent that enables people to adopt different livelihood strategies. Assets/stock in rupees possessed by respondents across all three zones is depicted in Table 6. Deposits in banks were lower in upper zone and significantly high in lower and middle zones. People living in lower zones have better opportunities for livelihood options and jobs as compared to middle and upper zone. The value of luxurious items was high in lower zone while as value of implements used in farming was high in upper zone than other two zones.

Livelihood strategies denote wide range of activities that households adopt in order to meet their livelihood needs. The sources of income of household found in study area were majorly classified into (i) agriculture and allied activities and (ii) off-farm income. The most common livelihood strategy of the respondents found as a manual labour in offfarm activities. Average household income from agriculture crop production system was lower in upper zone (0.70 lakh rupees)relative to lower zone (0.81 lakh rupees). Income from livestock products in upper zone was 0.74 lakh rupees while as 0.61 lakh rupees in middle zone and 0.52 lakh rupees in lower zone. Forest products contribute an average income of 0.46 lakh rupees per household in upper zone followed by 0.31 lakh rupees in middle and lower zones. On the other hand, income from public and private employment contributed about 0.91 lakh rupees of total income in upper zone and 1.44 lakh rupees in lower zone. Income earned from business 
Table 6: Financial capital (Stock and flows) across three zones

\begin{tabular}{|c|c|c|c|c|c|c|}
\hline \multirow{2}{*}{$\begin{array}{l}\text { Particulars } \\
\text { (A) Stocks }\end{array}$} & \multicolumn{2}{|c|}{ Lower zone } & \multicolumn{2}{|c|}{ Middle zone } & \multicolumn{2}{|c|}{ Upper zone } \\
\hline & Lac ₹ & $(\%)$ & Lac ₹ & $(\%)$ & Lac ₹ & $(\%)$ \\
\hline i) Deposits in banks & 0.94 & 6.52 & 0.83 & 6.50 & 0.1 & 0.85 \\
\hline ii) House & 10.13 & 70.30 & 8.07 & 63.19 & 7.75 & 66.24 \\
\hline iii) Jewellery & 0.80 & 5.55 & 1.1 & 7.42 & 0.50 & 4.27 \\
\hline iv) Livestock & 2.48 & 17.21 & 2.68 & 20.99 & 3.23 & 27.61 \\
\hline v) Tools and Implements & 0.06 & 0.42 & 0.09 & 0.70 & 0.12 & 1.03 \\
\hline Sub total & 14.41 & 100.00 & 12.77 & 100.00 & 11.70 & 100.00 \\
\hline \multicolumn{7}{|l|}{ (B) Income Flows from } \\
\hline i) Agriculture & 0.81 & 14.89 & 0.89 & 19.35 & 0.7 & 14.34 \\
\hline ii) Livestock & 0.52 & 9.56 & 0.61 & 13.26 & 0.74 & 15.16 \\
\hline iii) Forest product & 0.32 & 5.88 & 0.31 & 6.74 & 0.46 & 9.43 \\
\hline Sub total & 1.65 & 30.33 & 1.81 & 39.35 & 1.90 & 38.93 \\
\hline \multicolumn{7}{|l|}{ (C) Off -farm income } \\
\hline i) Employment (Public/Private) & 1.44 & 26.47 & 1.29 & 28.04 & 0.91 & 18.65 \\
\hline ii) Business & 0.85 & 15.63 & 0.21 & 4.57 & 0.25 & 5.12 \\
\hline iii) Labour & 1.50 & 27.57 & 1.29 & 28.04 & 1.82 & 37.30 \\
\hline Sub total & 3.79 & 69.67 & 2.79 & 60.65 & 2.98 & 61.07 \\
\hline Annual income & 5.44 & 100.00 & 4.60 & 100.00 & 4.88 & 100.00 \\
\hline
\end{tabular}

activities was high in lower zone due to more opportunities for commerce activities in relation to high altitude areas. Average income earned by doing labour work was 1.82 lakh rupees in upper zone followed by 1.29 lakh rupees in middle zone and 1.50 lakh in lower zone. Financial capital was found to be more concentrated in lower zone villages because of wide options for livelihoods and capital formation in relation to middle and upper zones.

\section{Social capital}

The networks of relationships among people who live and work in a particular society, enables that society to function effectively. In other words, social resources which people use in pursuit of their livelihood are commonly recognized as social capital. They are in form of networks and connectedness, membership of formal groups, and reciprocity. A few number of people was found to be affiliated with political parties in lower and middle zones; however no such kind of membership with any political party or NGO was observed in upper zone. However there is high connectivity of people across all three zones with panchayats.

\section{Capital Asset Pentagons}

The livelihood asset pentagon is perceived as a 'multidimensional process' which measures the socio-economic situation, as well as livelihood asset status with respect to study area. In general, livelihood asset pentagon measures the socioeconomic situation and it includes scores generated from livelihood assets. As the livelihood asset pentagon has multidimensional aspects, it includes financial asset, natural asset, social asset, human asset and physical asset. So that it is important to select true and representative parameters of sustainability of livelihood. Also it explains how much hilly people living in respective geographical location are privileged in owning the livelihood assets aggregating the inequities in the distribution and allocation. The livelihood asset framework is qualitative in its interpretation; therefore the interpretation of quantitative data received is the researcher's prerogative. It is the researchers conjecture that a visual indication and interpretation of the obtained results can assist in enhancing the understanding of people living in hills construct their livelihoods (Shaheen et al. 2017).

In this study, five major components considered are (i) human asset (ii) social asset (iii) natural asset (iv) financial asset and (v) physical asset. Each major component has several sub-components as mentioned earlier and shown in Table 7 which actually determine the livelihoods of individual, 
Table 7: Indicator and rank of capital assets

\begin{tabular}{|c|c|c|c|}
\hline \multirow[t]{2}{*}{ Indicators } & \multicolumn{3}{|c|}{ Ranks } \\
\hline & LZ & MZ & $\mathrm{UZ}$ \\
\hline HC1: \% of respondents with at least primary education & 2 & 1 & 1 \\
\hline HC2: \% of respondents with at least secondary education & 2 & 1 & 0 \\
\hline HC3: \% of respondents with access to healthcare & 1 & 2 & 1 \\
\hline HC4: \% respondents with access to extension services & 1 & 0 & 0 \\
\hline HC5: Awareness of education, health and extension programmes & 1 & 1 & 0 \\
\hline \multicolumn{4}{|l|}{ Natural Capital } \\
\hline NC1: Average size of holding & 1 & 1 & 2 \\
\hline NC2: Level of dependence on natural resource for livelihood & 1 & 2 & 2 \\
\hline NC3: Reliance on fuel wood for energy & 1 & 2 & 2 \\
\hline \multicolumn{4}{|l|}{ Physical Capital } \\
\hline PC1: Quality of roads in the area & 1 & 0 & 0 \\
\hline PC2: Access to piped water & 1 & 0 & 0 \\
\hline PC3: Quality of housing & 2 & 1 & 1 \\
\hline PC4: Usage of electricity/solar light & 1 & 1 & 0 \\
\hline \multicolumn{4}{|l|}{ Financial capital } \\
\hline FC1: Average annual income & 2 & 1 & 1 \\
\hline FC1: Possession of livestock & 1 & 1 & 2 \\
\hline FC1: Possession of valuable household items (jewellery, household asset, automobile) & 1 & 1 & 0 \\
\hline FC5: Importance of off -farm income & 2 & 1 & 1 \\
\hline \multicolumn{4}{|l|}{ Social capital } \\
\hline $\begin{array}{l}\text { SC1: Social network of relatives and friends available for assistance when seeking non- } \\
\text { farm work }\end{array}$ & 1 & 2 & 1 \\
\hline $\begin{array}{l}\text { SC2: Social network of relatives and friends available for assistance when in urgent need of } \\
\text { a lot of money }\end{array}$ & 2 & 1 & 2 \\
\hline SC3: Reliance and connectedness with panchayat/village groups & 1 & 1 & 2 \\
\hline
\end{tabular}

Note: $\mathrm{LZ}=$ lower zone; $\mathrm{MZ}$ = middle zone; $\mathrm{UZ}=$ Upper zone.

and how these influence the person in society. Asset pentagon is based on the score obtained by each indicator (component) of the capital asset. The Figure 2 of asset pentagon depicts that household lying in innermost pentagon represent the minimum level of asset or in other words we can say that household improve as we move away from the innermost pentagon. Based on score gained by the each capital it was observed that lower zone has higher score for financial capital (1.50) followed by human capital (1.40), social capital (1.33), physical capital (1.25), and natural capital (1.00). Middle zone received maximum scores in natural (1.67), social (1.33) and financial capital. As expected, Upper zone got maximum scores in natural capital i.e., 2.00 followed by social capital (1.67) and minimum in physical capital and human capital.

The lower zone is more skewed towards financial capital and less towards social and natural capital.

On the other hand, middle zone is more skewed towards natural and social capital. However, Upper zone was found to be more skewed towards natural and social capital than other capital assets. Thus on the basis of above observation it can be concluded that household who are living in upper and middle reaches of study area are found to be more vulnerable to economic shocks and health issue and poverty shocks and thus more prone to various unsustainable livelihood issue thus it could be seen that is clear bias with the household living in upper and middle reaches of mountainous area. The household living in upper zone having high score for natural capital indicated that some effort should be taken to for proper management and preventing of natural resource viz., forests, pastures, grasslands and other natural resources from being over exploited. 


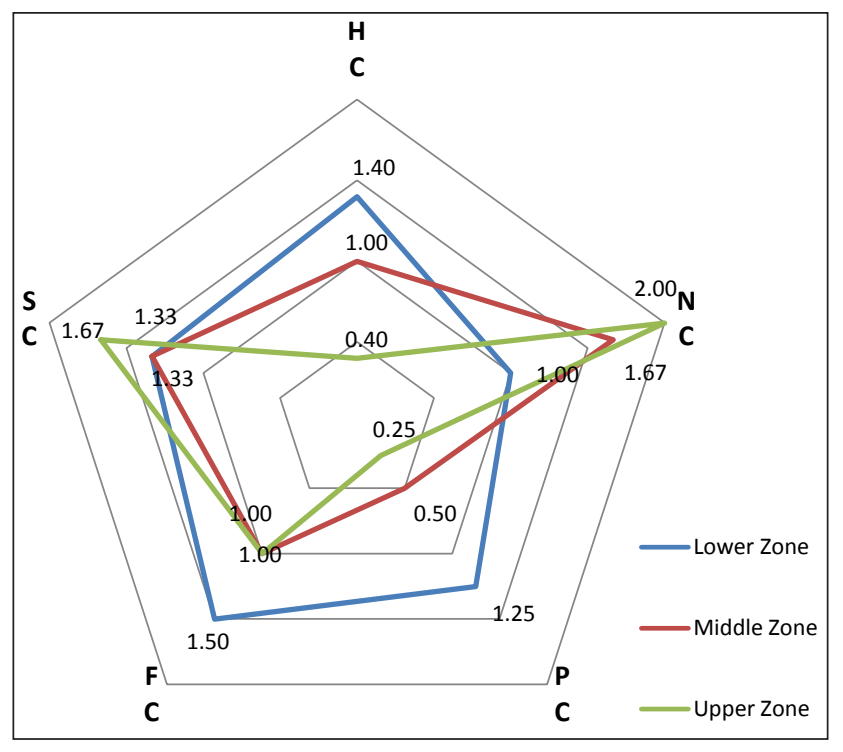

Fig. 2: Capital Asset Pentagons

\section{CONCLUSION}

The various facets of capital formation to support tribal livelihoods in intermediate zone were comprehensively analysed. People living in higher reaches of hills were found more dependent on agriculture and animal husbandry practices besides harvesting the natural resources for sustaining their livelihoods. Though the region is transforming steadily but still it fall deficit with respect to number of socio-economic overheads. The transformation and diversification of livelihood economy is restricted in lower zone villages whereas upper areas have lesser opportunities to diversify their livelihood portfolios. There is need for education infrastructure and other social capital overheads in upper zones. Furthermore, extension agencies need to gear-up their outreach to these high altitude areas in providing better input technologies in agriculture and animal husbandry. Natural resources need to sustain through participatory approach through some major rural flagship programs such as MGNREGA, IWDP etc., which will create both job opportunities as well as capital good infrastructure which can in turn increase the productive potential of such areas.

\section{REFERENCES}

Anonymous. 2011. Available in <http:// www.jkapd.nic.in/ overview of Jammu and Kashmir.

Anonymous. 2017. Regional Digest of Statistics, Government of Jammu and Kashmir. Directorate of Economics and Statistics J\&K., pp. 58.

Carney, D. 1998. Implementing the sustainable rural livelihoods approach, Chapter, Sustainable rural livelihood: What contribute can we make? Department of international Development, London U.K.

Department for International Development (DFID) (1999), Sustainable Livelihood Guidance Sheet Framework, 2.1, U.K.

Gardner, G. 1996. Shrinking fields: crop land loss in a words of eight billion, world watch paper 161, world watch institute Washington DC.

Pratap, T. 2001. Mountain agriculture, marginal lands and sustainable livelihood: challenges and opportunities, international symposium on mountain agriculture in HKH region, 21-24 May, ICIMOD, Kathmandu, Nepal.

Rasul, G. and Karki, M. 2007. A pro-poor policy agenda for sustainable agricultural development in the HinduKush Himalayan region. International Centre for Integrated Mountain Development (ICIMOD). Journal of Economics and Sustainable Development, 4(20): 96-103.

Shaheen, F.A., Wani, S.A., Baba, S.H. and Farheen Naqash. 2017. Disadvantaged mountain farmers of Gurez valley in Kashmir: Issues of livelihood, vulnerability, externality and sustainability, Indian Journal of Agricultural Economics, 72(3): 456-474. 
